\title{
The Factors Influence the Pre-service Teachers' Learning in the Practicum
}

\author{
Tien Nguyen ${ }^{1 *}$ \\ ${ }^{1}$ Deakin University, Australia \\ *Correspondence: tiennvt@hcmute.edu.vn
}

\begin{abstract}
The practicum in teacher education is considered as the application of the theory into practice. (Zeichner, 2009). However, the disconnection between the academic learning and practicum (Alen \& Wright, 2014; Kwenda et al.2017) has been a barrier for pre-service teachers' learning. My research introduces a new approach to bridge this gap by comparing an on-campus and an off-campus practicum. In the on-campus practicum, the lecturers in academic learning stage also mentor the pre-service teachers in the practicum. Sociocultural Theory (Vygotsky, 1978) and Activity Theory (Engeström, 2015) are used as the tool for data analysis. The participants, included the university leaders, lecturers, mentors and pre-service teachers of two English language faculties in Vietnam were interviewed, the pre-service teachers were observed and formal documents were analysed. The findings indicated that the systematic change in the on-campus practicum facilitates the translation between theory and practice. In addition, the long-term relationship resulted in the devotion of the mentors to their mentees. In the meanwhile, the pre-service teachers in the off-campus practicum bounced between the two separated systems and suffered more tensions.
\end{abstract}

Keywords: teacher education, practicum, pre-service teachers, learning, mentoring

\section{Introduction}

The practicum in teacher education is an essential opportunity for pre-service teachers to build their pedagogical competence as teachers in the real classroom context. As Allen and Wright (2014, p. Received October 10, 2020; revised October 21, 2020; accepted November 10, 2020; electronically published January 31 , 2021

Journal of Comparative \& International Higher Education

December, 2020, Vol. 12, No. 6S1, pp. 31-36.

DOI: $10.32674 /$ jcihe.v12i6S1.3089

(C) 2020 Journal of Comparative \& International Higher Education. All rights reserved. 
137) argue, the practicum "has always been integral to teacher education programs and represents the time during which students are ideally provided opportunities to integrate theory and practice in the workplace". Although the practicum is considered as the opportunity to apply theory (Azkiyah \& Mukminin, 2017; Zeichner, 2009), critics of the practicum in teacher education point to the theory and practice divide as a current issue (Gan, 2013; Yin, 2019). The fact that universities provide theoretical knowledge and schools are responsible for the practice of the theory (Allen \& Wright, 2014; Kwenda, Adendorff, \& Mosito, 2017) has caused the difficulties for pre-service teachers in translating theory into practice. The hybrid space where academic knowledge and practical knowledge meet has been a suggestion for theory-practice integration (Soja \& Chouinard, 1999). However, this solution can be implemented only when universities and schools have mutual benefits (Bloomfield \& Nguyen, 2015), otherwise the collaboration between universities and schools is insignificant. In reality, "tensions have occurred on multiple occasions" in the hybrid space (Taylor et al., 2013, p. 9). In Vietnam, the practicum has echoed concerns on the weak partnership between universities and schools (Nguyen, 2015) and contrasting teaching approaches between them (Nguyen et al., 2015). As a result, pre-service teachers have to choose either to comply with their school mentors or to struggle with tensions (Le, 2014). There has been no research that investigates hybrid space for universities and schools to share knowledge so far.

In the attempt to bridge this gap, my research compares a traditional practicum and an innovative practicum. In the traditional practicum, the pre-service teachers were sent to local schools and they were mentored by the local schoolteachers. In the innovative on-campus practicum, the preservice teachers practiced teaching within campus and were mentored by the university lecturers who had been responsible for their academic courses. All the pre-service teachers were final-year-students of the four-year degree program in English language teacher education in two universities of Vietnam. 
Drawing on Sociocultural Theory (Vygotsky, 1978) and Activity Theory (Engeström, 2015), my research examines the pre-service teachers' cognitive process of learning to teach as well as the factors that might influence the pre-service teachers' learning in the practicums. The factors that might impact their learning include the sociocultural context of the local schools where the practicum is organized, and the socio-historical context of their academic learning at the university. The three main concepts employed are Zone of Proximal Development (Sociocultural Theory), Boundary Crossing, and Contradiction (Activity Theory). These concepts are used as analytical tools to interpret pre-service teachers' learning and interactions between the universities and the local schools, as well as between the mentors and the mentees.

\section{Methodology}

This qualitative research employs a case study design. There were thirty-seven participants, including two university leaders, two faculty leaders, eight lectures, twenty-two pre-service teachers and three local school mentors. The leading university in teacher education organized the practicum off campus, where the pre-service teachers taught the learners of Year 10 and Year 11. Meanwhile, the merging university organized the practicum on campus, where the pre-service teachers taught first year students who did not major in English language. This means the pre-service teachers in the on-campus practicum were situated in their mentors' General English classes to teach their mentors' students. Although the textbooks used in two practicums were different, the pre-service teachers in both practicums mainly taught learners at the pre-intermediate level. Semi-structured interviews with all participants and observations with twenty-two pre-service teachers were conducted. The interview and observation data were then triangulated with the official documents of two university websites to unpack the pre-service teachers' learning as well as the factors that influence their learning. The triangulation of data collection and data analysis ensured the cross-verification that enhances the credibility of the data. 


\section{Findings}

The findings indicate that the different mechanisms of off-campus and on-campus practicum impacted the pre-service teachers' learning.

Firstly, concerning the integration between academic learning stage and the practicum, the preservice teachers of the off-campus practicum bounced between two separated organizations of the university and the local school. The socio-historical differences resulted in the hindrances to the movement from university system to the local school system, which impacted the translation between theory and practice. On the contrary, the findings in the on-campus practicum showed the systematic integration between two stages of teacher education. When the university lecturers took the role of mentors, they became the connectors between the two-direction movements of theory and practice. Besides supporting the pre-service teachers in the light of theory, the university lecturers also saw the gap between two stages when observing the pre-service teachers' teaching, which is beneficial for the curriculum revision and lecture adaptation. The faculty leaders were responsible for supervising the integration of the mentoring system and the learning-to-teach system to ensure the entire system works well.

Secondly, the relationship between mentors and mentees also influenced the mentoring and the learning-to-teach. In the traditional off-campus practicum, despite the fact that the mentors were experienced as the practitioners, the pre-service teachers' learning was not the mentors' priority. The inexperience of the pre-service teachers caused tension as it negatively impacted the local school learners. Moreover, with the fixed mindset in the boundaries of the local schools, the local school mentors did not encourage the ideas, which were unfamiliar with the established rules. This prevented the professional development of the pre-service teachers. On the contrary, the long-term relationship between mentors and mentees in the on-campus practicum for three and a half years resulted in the 
care and devotion of the mentors to the mentees. Being empowered by their mentors, the pre-service teachers had more opportunities to put their new ideas into practice.

\section{Significance}

The research contributes knowledge to the organizational learning and innovation to bridge the gap between theory and practice. As a result, it enhances the quality of the practicum in teacher education. Although the research was conducted in the context of English language teacher education in Vietnam, the contrasting features of the off-campus and on-campus practicum addresses the issues of teacher education not only in Asian countries but across the world as well. It is significant as it suggests a new pathway to cross the boundaries between two stages of teacher education.

\section{Author Note}

Thuy-Tien V. Nguyen is a PhD candidate in School of Education, Deakin University, Australia. Her thesis is closely linked to her work experience as a lecturer and a mentor in Ho Chi Minh University of Technology and Education, Vietnam. Her research interest focuses on Pre-service Teachers' learning and Mentoring.

\section{References}

Allen, J. M., \& Wright, S. E. (2014). Integrating theory and practice in the pre-service teacher education practicum. Teachers and Teaching, 20(2), 136-151.

Azkiyah, S. N.; Mukminin, A. (2017). In search of teaching quality of EFL student teachers through teaching practicum: Lesson from a teacher education program. Center for Educational Policy Studies Journal, 7(4), 105-124. https://files.eric.ed.gov/fulltext/EJ1165342.pdf 
Bloomfield, D., \& Nguyen, H. T. M. (2015). Creating and sustaining professional learning partnerships: Activity Theory as an analytic tool. Australian Journal of Teacher Education, 40(11), 2.

Engeström, Y. (2015). Learning by Expanding (2nd ed.). Cambridge University Press.

Gan, Z. (2013). Learning to teach english language in the practicum: What challenges do non-native ESL student teachers face?, Australian Journal of Teacher Education, 38(3), 92-108.

Kwenda, C., Adendorff, S., \& Mosito, C. (2017). Student-teachers' understanding of the role of theory in their practice. Journal of Education (University of KwaZulu-Natal)(69), 139-160.

Le, L. C. (2014). Great expectations: The TESOL practicum as a professional learning experience. TESOL Journal, 5(2), 199-224.

Nguyen, H. P. C. (2015). EFL teaching practicums in Vietnam: The vexed partnership between universities and schools. Electronic Journal of Foreign Language Teaching, 12(2), 169-182.

Nguyen, H. T., Fehring, H., \& Warren, W. (2015). EFL teaching and learning at a Vietnamese university: What do teachers say? English Language Teaching, 8(1), 31-43.

Taylor, M., Klein, E., \& Abrams, A. (2014). Tensions of reimaging our roles as teacher educators in a third space: Revisiting a co/autoethnography through a faculty lens. Studying Teacher Education, 10 (1), 3-19.

Soja, E. W., \& Chouinard, V. (1999). Thirdspace: journeys to Los Angeles \& other real \& imagined places. Canadian Geographer, 43(2), 209.

Vygotsky, L. S. (1978). Mind in Society : Development of Higher Psychological Processes. M. Cole, V. JohnSteiner, S. Scribner, \& E. Souberman (Eds.). Harvard University Press.

Yin, J. (2019). Connecting theory and practice in teacher education: English-as-a-foreign-language preservice teachers' perceptions of practicum experience. Innovation and Education, 1(4), 1-8.

Zeichner, K. (2009). Rethinking the connections between campus courses and field experiences in college- and university-based teacher education. Journal of Teacher Education, 61(1-2), 89-99. 